\title{
KINERJA KEUANGAN SEBELUM DAN SESUDAH AKUISISI PADA PERUSAHAAN NON-KEUANGAN
}

\author{
Satriana Gandamihardja \\ satrianag@gmail.com \\ Ellen Rusliati \\ Universitas Pasundan \\ J1. Tamansari No. 6-8, Bandung 40116
}

diterima: 20/12/2019; direvisi: 26/1/2020; disetujui: 28/4/2020

\begin{abstract}
A phenomenon in the company's strategy in carrying out business development is mergers and acquisitions. In fact, the company prefers acquisition as its strategy, but it still lacks synergies after making acquisitions. The purpose of this study is to compare the financial performance before and after the acquisition of non-financial companies listed on the Indonesia Stock Exchange in 2012. The population are 31 companies that make acquisitions. The method used is descriptive and verification methods, with paired sample t-test. Based on the hypothesis test, the results showed that the current ratio, total asset turnover, debt to equity ratio did not have a significant difference between before and after the company made the acquisition, while the return on assets has a difference, but was decreasing. The acquirer needs to measure the performance of the company being acquired and project the performance and risk after the acquisition.
\end{abstract}

Keywords: current ratio; total asset turnover; debt to equity; return on assets; acquisitions

\begin{abstract}
Abstrak
Fenomena dalam strategi perusahaan dalam melakukan pengembangan usaha adalah merger dan akuisisi. Pada kenyataannya, perusahaan lebih memilih akuisisi sebagai strateginya, namun masih memiliki kekurangan dalam hal sinergi setelah melakukan akuisisi. Tujuan penelitian ini adalah untuk membandingkan kinerja keuangan sebelum dan sesudah akuisisi pada perusahaan non-keuangan yang terdaftar pada Bursa Efek Indonesia tahun 2012. Populasi adalah perusahaan yang melakukan akuisisi berjumlah 31. Metode yang digunakan adalah metode deskriptif dan verifikatif, dengan t-test paired sample. Berdasarkan uji hipotesis, diperoleh hasil bahwa current ratio, total asset turnover, debt to equity ratio tidak memiliki perbedaan signifikan antara sebelum dengan setelah perusahaan melakukan akuisisi, sedangkan return on asset terdapat perbedaan, namun semakin menurun. Pengakusisi perlu mengukur kinerja perusahaan yang diakusisi dan memproyeksikan kinerja dan risiko setelah akuisisi.
\end{abstract}

Kata Kunci: current ratio; total asset turnover; debt to equity; return on asset; akuisisi 


\section{PENDAHULUAN}

Perusahaan di era globalisasi yang dinamis dituntut untuk lebih kreatif dalam menjalankan bisnisnya seiring dengan perkembangan yang terjadi dalam dunia bisnis yang terus bersaing memperebutkan eksistensi masingmasing perusahaan. Hal tersebut juga ditentukan oleh kuat atau tidaknya pasar yang dimiliki perusahaan. Perusahaan mempunyai siklus hidup yang tidak dapat diprediksi dengan tepat, sehingga dituntut untuk terus menerus meningkatkan kinerjanya apabila ingin bertahan pada situasi persaingan yang semakin ketat.

Kinerja keuangan merupakan indikator penilaian untuk perusahaan dalam membuktikan keberhasilan dan pencapaian target. Pengukuran kinerja keuangan digunakan untuk mengevaluasi perubahan sumber daya yang ada sehingga dapat diketahui kelebihan perusahaan yang harus tetap dikembangkan dan kelemahan yang harus diperbaiki. Analisis laporan keuangan memungkinkan untuk membandingkan kinerja perusahaan satu dengan lainnya pada industri yang sama dan mengevaluasi kecenderungan posisi keuangan setiap saat.

Bermacam strategi perlu dimiliki perusahaan dalam usahanya meningkatkan kinerja keuangan dan mencapai tujuannya. Diantaranya adalah melakukan peningkatan perusahaan secara internal maupun eksternal. Pertumbuhan internal adalah ekspansi yang dilakukan dengan membangun bisnis atau unit bisnis baru dari awal. Jalur ini memerlukan berbagai tahap mulai dari riset pasar, desain produk, perekrutan tenaga kerja, tes pasar, pengadaan operasional. Sebaliknya, pertumbuhan eksternal dilakukan dengan membeli perusahaan yang sudah ada. Pertumbuhan ini biasa dikenal dengan penggabungan usaha yang pada umumnya dilakukan dalam bentuk merger, akuisisi, dan konsolidasi.

Merger dan akuisisi yang dilakukan dengan harapan dapat melanjutkan usahanya melalui bantuan serta kerjasama dengan perusahaan lain dan mencapai tujuan. Merger dan akuisisi adalah strategi pertumbuhan eksternal dan merupakan jalur cepat untuk mengakses pasar produk baru tanpa harus membangun dari awal. Terdapat penghematan waktu yang sangat signifikan antara pertumbuhan eksternal, melalui merger dan akuisisi, dibanding internal. Aktivitas merger dan akuisisi di Indonesia mulai banyak dilakukan seiring dengan majunya pasar modal di Indonesia. Tahun 2010 menunjukkan merger dan akuisisi banyak terjadi Indonesia, menurut data Komisi Pengawasan Persaingan Usaha (KPPU), dan diperkirakan akan terus meningkat di masa mendatang. Merger dan akuisisi di Indonesia telah berkembang sedemikian rupa sehingga menjadi sebuah strategi yang diminati dalam meningkatkan kinerja perusahaan.

Gambar 1 menunjukkan strategi akuisisi lebih diminati, karena dianggap jalan cepat untuk mewujudkan tujuan. Perusahaan hanya melakukan pengambil-alihan perusahaan yang sedang mengalami krisis dan menjadikannya anak perusahaan. Strategi merger adalah penggabungan kedua perusahaan sehingga perusahaan yang diambil-alih hilang, semua aktiva dan hutangnya digabung kepada perusahaan yang mengambilalih.

Akuisisi dapat dikatakan ekspansi, apabila melakukan peluasan modal, baik modal kerja saja atau modal kerja dan modal tetap, serta menyebabkan perubahan struktur modal. Akuisisi dapat menjadi capital split (pembagian modal) apabila perusahaan menggunakan dana yang ada di dalam perusahaan seperti laba ditahan, sehingga tidak menyebabkan perubahan pada struktur modal.

Analisis kinerja keuangan bertujuan untuk menilai implementasi strategi perusahaan dalam akuisisi. Kinerja diartikan sebagai prestasi yang dicapai oleh manajemen keuangan dalam mencapai tujuan untuk menghasilkan keuntungan dan meningkatkan nilai perusahaan. Kinerja perusahaan dapat dinilai menggunakan rasio keuangan dengan membandingkan neraca perusahaan sebelum dan setelah melakukan akuisisi.

Penelitian yang dilakukan oleh (Fatima \& Shehzad, 2014), menunjukkan bahwa akuisisi tidak berhasil mengubah laba setelah pajak, Return on Assest (ROA), leverage, Debt to Equity Ratio (DER), dan Earning Per Share (EPS), namun Return On Equity (ROE) terjadi perubahan yang signifikan. Hal ini berarti akuisisi tidak tepat untuk mencapai sinergi juga memenuhi skala ekonomi, karena tidak memberi efek positif pada kinerja perbankan di Pakistan. Demikian pula penelitian (Abbas et al., 2014) pada perbankan di Pakistan, bahwa merger dan akuisisi tidak berhasil meningkatkan kinerja perbankan. (Ahmed \& Ahmed, 2014) yang melakukan penelitian pada perusahaan manufaktur di Pakistan munjukkan bahwa merger dan akuisisi tidak berhasil mengubah posisi likuiditas, profitabilitas, dan posisi modal secara signifikan.

Hasil berbeda ditunjukkan (Akenga \& Olang, 2017), bahwa merger dan akuisisi pada bank komersial di Kenya berhasil meningkatkan ROE dan penurunan biaya, sehingga terjadi sinergi dan peningkatan nilai perusahaan secara signifikan. Demikian pula penelitian yang dilakukan (Aprilianti, 2013) menunjukkan adanya peningkatan kinerja keuangan setelah melakukan akuisisi selama 4 periode.

Menurut (Sudana, 2011) akuisisi adalah penggabungan dua perusahaan. Akuisitor membeli sebagian saham perusahaan yang diakuisisi, sehingga pengendaliannya berpindah kepada akuisitor, sementara kedua perusahaan masing-masing tetap beroperasi sebagai suatu badan hukum yang berdiri sendiri. Akuisisi strategi terjadi ketika perusahaan mengakuisisi perusahaan lainnya sebagai bagian dari strategi keseluruhan (Van Horne, James C; Wachowicz, John M., 2012). 
Kinerja perusahaan adalah suatu usaha formal yang dilaksanakan untuk mengevaluasi efisiensi dan efektivitas aktivitas perusahaan yang telah dilaksanakan pada periode waktu tertentu. Kinerja keuangan perusahaan merupakan hasil dari banyak keputusan individual yang dibuat secara terus menerus oleh manajemen. Tujuan akuisisi adalah untuk memperbaiki sistem manajemen perusahaan terakuisisi, yang manajemennya lemah, sulit berkembang walaupun mempunyai cukup dana, sehingga tidak mampu bersaing dengan perusahaan lain.

Perusahaan yang sedang dalam keadaan tidak baik dapat diakuisisi oleh perusahaan lain yang lebih besar dan sehat, dengan harapan perusahaan yang diambilalih dapat meningkatkan kinerjanya (Hariyani, Iswi; D. P., Serfiyanto; Serfiyani, 2011). Hasil penelitian (Bouzgarrou, 2014) menunjukkan bahwa akuisisi bagi perusahaaan besar dengan keuntungan yang tinggi cenderung menggunakan dana yang bersumber dari hutang, berarti pemilik tidak bersedia kekurangan kepemilikannya atas perusahaan, dan memiliki kemampuan untuk membayar kewajibannya. Sebaliknya perusahaan yang berpengalaman mengakuisisi dan memperoleh kenaikan harga saham atas akuisisi yang dilakukan lebih menyukai modal sendiri untuk pendanaannya.

Perubahan yang terjadi setelah perusahaan melakukan akuisisi akan terlihat pada kinerja keuangan. Keberhasilan perusahaan dalam melakukan akuisisi dapat dinilai dari perbandingan hasil kinerja keuangan sebelum dan sesudah akuisisi. Akuisisi dikatakan berhasil bila kinerja keuangan meningkat. Setelah akuisisi kondisi dan posisi keuangan mengalami perubahan dan tercermin dalam laporan keuangan perusahaan yang melakukan akuisisi. Sinergi yang terjadi pada akuisisi akan meningkatkan kemampuan perusahaan dalam memperoleh laba sehingga profitabilitas meningkat. Hal ini diperkuat oleh penelitian yang dilakukan (Prasad, 2019) menunjukkan perusahaan setelah melakukan akuisisi terjadi peningkatan pada rasio profitabilitas. Penelitian yang dilakukan (Prasetyo, 2008) menunjukkan adanya perbedaan yang signifikan tingkat likuiditas yang diukur dengan CR, leverage yang diukur dengan DER, aktivitas yang diukur dengan TATO, dan profitabilitas yang diukur dengan ROA setelah perusahaan melakukan akuisisi.

Penelitian ini memfokuskan pada perbandingan kinerja keuangan sebelum dan sesudah akuisisi pada perusahaan non-keuangan yang terdaftar di BEI. Tujuan penelitian ini adalah untuk mengetahui dan menganalisis: (1) Kondisi Current Ratio (CR), Total Asset Turnover (TATO), Debt to Equity Ratio (DER), dan Return On Aset (ROA) pada perusahaan yang melakukan akuisisi tahun 2012. (2) Perbedaan CR, TATO, DER, ROA sebelum dan sesudah akuisisi pada perusahaan yang melakukan akuisisi tahun 2012 .

\section{METODE}

Penelitian ini menggunakan pendekatan metode kuantitatif dengan analisis komparatif. Populasi dalam penelitian ini adalah seluruh perusahaan yang tercatat di KPPU melakukan kegiatan akuisisi dan terdaftar di BEI pada tahun 2012 sebanyak 11 perusahaan. Teknik pengambilan sampel yang digunakan adalah purposive sampling, dengan ketetentuan: (1) Terdapat laporan keuangan 2 tahun sebelum dan sesudah akuisisi. (2) Tidak bergerak di sektor keuangan dan bank. Jumlah sampel sebanyak 9 perusahaan. Teknik analisis yang digunakan adalah analisis deskriptif dan kuantitaif dengan dan uji statistik $\mathrm{t}$ test sample related.

\section{HASIL}

Hasil analisis deskriptif ditunjukkan pada Tabel 1. CR yang menunjukkan kemampuan perusahaan untuk membayar kewajiban jangka pendeknya dengan menggunakan aktiva lancarnya (Van Horne, James C; Wachowicz, John M., 2012). Perusahaan yang memiliki CR tertinggi sebesar 90,01, berarti perusahaan tidak memutar aktiva lancarnya. Hal ini dapat berdampak negatif, karena menurut (Munawir, 2010) tingkat CR yang memuaskan dan dianggap aman bagi perusahaan sebesar 2. Perusahaan dengan CR terendah dapat menimbulkan risiko yang besar, karena apabila perusahaan membutuhkan dana untuk membayar hutang jangka pendeknya perusahaan tidak dapat membayar segera hutang lancar tersebut.

TATO merupakan rasio yang digunakan untuk mengukur perputaran semua aktiva yang dimiliki perusahaan dan mengukur berapa jumlah penjualan yang diperoleh dari tiap rupiah aktiva (Kasmir, 2018). TATO yang tinggi menunjukkan bahwa aset perusahaan digunakan dengan baik sehingga perputaran aset menjadi cepat. TATO dinilai baik apabila rasio tahun berjalan lebih baik dari tahun sebelumnya, sehingga rasio ini membandingkan kinerja kemarin dengan sekarang.

Menurut(Brigham \& Houston, 2019) DER digunakan untuk mengukur sejauh mana perusahaan dibiayai dengan hutang. Semakin tinggi DER menunjukan komposisi total hutang semakin besar dibanding dengan total modal sendiri, sehingga berdampak semakin besar beban perusahaan terhadap pihak luar. DER lebih dari 1 menunjukan risiko yang tinggi dalam pertumbuhan kinerja, sebab perusahaan lebih banyak dibiayai oleh hutang yang dapat berisiko juga terhadap likuiditas perusahaan. Nilai DER yang kurang dari 1 menunjukkan tingkat modal perusahaan yang dibiayai lebih banyak oleh modal sendiri daripada hutang. Bagi kreditur, kondisi DER yang rendah memiliki risiko yang rendah, sehingga akan memberikan pinjaman, akan tetapi bagi perusahaan hal ini menimbulkan risiko yang tinggi karena modal dibiayai oleh modal pemilik sehingga apabila perusahaan mengalami pailit pemilik modal akan merasa merugi. 
Profitabilitas menunjukkan hubungan antara pendapatan dan biaya yang timbul sebagai akibat penggunaan aset, baik lancar maupun tetap, dalam kegiatan produktif (Gitman, Lawrence J. and Zutter, 2015).

Hasil perhitungan CR, TATO, DER, dan ROA sebelum dan sesudah akuisisi ditunjukkan pada Tabel 2. Uji hipotesis digunakan t-test sample related. Hasil perhitungan dengan menggunakan SPSS 20.0 ditunjukkan pada Tabel 3, menjelaskan bahwa tidak ada perbedaan signifikan antara CR, TATO, DER sebelum dan sesudah akuisisi pada perusahaan non-finansial yang terdaftar di BEI pada tahun 2012, namun ROA terdapat perbedaan signifikan.

\section{PEMBAHASAN}

$\mathrm{CR}$ atau rasio likuiditas menunjukkan kemampuan perusahaan dalam membayar hutang jangka pendek dengan menggunakan aktiva lancar. Berdasarkan perhitungan rasio likuiditas, dapat diketahui bahwa rata-rata rasio likuiditas berada dalam keadaan baik, walaupun tampak terlalu tinggi sebelum akuisisi dan memiliki kecenderungan menurun setelah akuisisi. Dapat dikatakan bahwa rata-rata perusahaan yang melakukan akuisisi di masa transisi di tahun 2010 hingga 2014 tetap dapat membayar hutang jangka pendek dengan menggunakan aktiva lancar.

TATO mengukur seberapa baik perusahaan mengelola aset untuk meningkatkan laba dari penjualan. Perubahan yang terjadi dari tahun 2010 hingga 2014 memiliki kecenderungan menurun, berarti terjadi penurunan kemampuan pengelolaan aset.

DER menunjukkan rasio pembiayaan perusahaan dengan hutang. Semakin tinggi, maka tingkat hutang dan beban perusahaan semakin besar. Rata-rata rasio DER berada kurang dari 1, menunjukkan kecilnya pembiayaan perusahaan yang berasal dari hutang. namun, peningkatan terjadi saat tahun akuisisi perusahaan dari tahun 2012 hingga 2014 yang menunjukkan nilai rasio di atas 1 kali. Hal tersebut dapat menunjukkan bahwa rata-rata perusahaan setelah akuisisi lebih banyak menggunakan hutang daripada modal sendiri.

ROA adalah rasio yang digunakan untuk mengukur kemampuan perusahaan untuk menghasilkan laba selama periode tertentu. Semakin tinggi nilai rasio maka akan semakin baik tingkat pengembalian asetnya. Pada tahun 2010 hingga 2011 mengalami peningkatan yang cukup baik, namun setelah akuisisi terdapat penurunan yang cukup besar.

Kondisi CR sebelum dengan setelah perusahaan melakukan akuisisi tidak menunjukkan perbedaan yang signifikan. Hal ini diperkuat oleh penelitian (Gunawan, Kadek Hendra; Sukartha, 2013). Nilai rata-rata CR perusahaan non-keuangan yang melakukan akuisisi menunjukan tren negatif, setiap tahunnya terus menurun. Sebelum perusahaan melakukan akuisisi CR cukup baik bahkan terlalu tinggi, menurut (Hery, 2016) nilai $\mathrm{CR}$ yang ideal bagi perusahaan adalah 2 kali. Kondisi nilai rata-rata $\mathrm{CR}$ setelah melakukan akuisisi menurun menjadi di bawah kondisi ideal, hal ini disebabkan sinergi positif yang diharapkan oleh perusahaan tidak terjadi dan kurang baiknya mengelola tingkat likuiditas.

Kondisi TATO tidak terdapat perbedaan sebelum maupun sesudah perusahaan melakukan akuisisi. Penelitian ini sejalan dengan (Prasetyo, 2008). Kondisi TATO sebelum perusahaan melakukan akuisisi menunjukkan peningkatan akan tetapi menurun setelah perusahaan melakukan akuisisi. TATO setelah akuisisi yang menurun dapat disebabkan oleh adanya aset yang tidak dimanfaatkan untuk menghasikan penjualan dan tingkat penjualan menurun.

Kondisi DER tidak terdapat perbedaan sebelum maupun sesudah perusahaan melakukan akuisisi. Penelitian ini sejalan dengan (Aprilianti, 2013), (Fatima \& Shehzad, 2014), (Abbas et al., 2014). Hal ini menunjukkan bahwa pengakuisisi berupaya untuk mempertahankan posisi struktur modal (Van Horne, James C; Wachowicz, John M., 2012), yaitu berkisar di angka 1, walaupunn terdapat kecenderungan meningkat.

Kondisi ROA terdapat perbedaan signifikan sebelum dan sesudah akuisisi. ROA menurun sebelum perusahaan melakukan akuisisi, namun semakin menurun setelah akuisisi dilakukan. Hasil ini sejalan dengan penelitian (Sharma, 2016) dan (Tang, 2015). Akuisisi belum menunjukkan hasil sesuai dengan harapan setelah 2 tahun akuisisi, bahkan profitabilitas semakin menurun, karena masa transisi atau kinerja perusahaan yang diakuisisi berkinerja sangat buruk.

Hasil penelitian ini menunjukkan terjadinya penurunan profitabilitas secara signifikan, likuiditas dan aktivitas (tidak signifikan), dan peningkatan leverage (tidak signifikan). Hasil ini memperkuat penelitian (Ahmed \& Ahmed, 2014), (Zen et al., 2016) bahwa merger dan akuisisi tidak berpengaruh terhadap kinerja keuangan. Kinerja merupakan hasil dari berbagai faktor, seperti reorganisasi bisnis, krisis, depresi bisnis, dan sebagainya, yang berdampak jangka panjang. (Mishra, 2019)mengemukakan intensitas modal, upaya yang berhubungan dengan pemasaran dan distribusi, perkembangan teknologi dan investasi, dapat mempengaruhi kinerja keuangan melalui struktur pasar dengan strategi bisnis, efisiensi, dan persaingan.

\section{KESIMPULAN}

Kondisi kinerja keuangan yang diukur dengan tingkat likuiditas dan profitabilitas cenderung menurun. Aktivitas berfluktuasi, namun cenderung stabil, tingkat leverage cenderung meningkat. Akuisisi mengakibatkan aktiva cenderung meningkat akan tetapi penjualan cenderung menurun. Tidak ada perbedaan pada likuiditas, aktivitas, dan leverage sebelum dan setelah akuisisi, namun profitabilitas mengalami 
perbedaan signifikan akan tetapi semakin menurun. Perbaikan kinerja keuangan dipengaruhi oleh banyak faktor, akuisisi tidak selalu membawa perusahaan ke arah yang lebih baik. Penting bagi pengakuisis untuk memilih perusahaan yang diakuisisi tidak akan menekan kinerja dan melakukan proyeksi setelah akuisisi dan kemungkinan risikonya.

\section{DAFTAR PUSTAKA}

Abbas, Q., . R. S., . E.-U.-H., \& . M. S. I. 2014. Analysis of Pre and Post Merger and Acquisition Financial Performance of Banks in Pakistan. Information Management and Business Review, 6(4), 177-190. https://doi.org/10.22610/imbr.v6i4.1113

Ahmed, M., \&Ahmed, Z. 2014. Mergers and Acquisitions: Effect on Financial Performance of Manufacturing Companies of Pakistan. Middle-East Journal of Scientific Research, 21(4), 706-716. https://doi. org/10.5829/idosi.mejsr.2014.21.04.21442

Akenga, G. M., \& Olang, M. A. 2017. Effect of Mergers and Acquisitions on Financial Performance of Commercial Banks in Kenya. IOSR Journal of Business and Management, 19(8), 84-90. https:// doi.org/10.9790/487X-1908038490

Aprilianti, A. 2013. Analisis Kinerja Keuangan Perusahaan Sebelum dan Sesudah Melakukan Transaksi Akuisisi (Studi Kasus Pada Akuisisi PT. Indofood Sukses Makmur,Tbk Terhadap PT. Indolakto). Jurnal Ilmiah Mahasiswa Fakultas Ekonomi dan Bisnis, 53(9), 1689-1699.

Bouzgarrou, H. 2014. Financing decision in acquisitions : The role of family control. Procedia Economics and Finance, 13(December 2013), 3-13. https://doi.org/10.1016/S2212-5671(14)00426-2

Brigham, E. F., \& Houston, J. F. 2019. Fundamentals of Financial Management 15 Edition. Cengage Learning.

Fatima, T., \& Shehzad, A. 2014. An Analysis of Impact of Merger and Acquisition of Financial Performance of Banks: A case of Pakistan. Journal of Poverty, Investment and Development-An Open Access International Journal, 5, 29.

Gitman, Lawrence J. and Zutter, C. J. 2015. Principle of Management Finance (Fourteen). Pearson Education Limited.
Gunawan, Kadek Hendra; Sukartha, I. M. 2013. Kinerja Pasar Dan Kinerja Keuangan Sesudah Merger Dan Akuisisi Di Bursa Efek Indonesia. E-Jurnal Akuntansi Univesitas Udayana, 5(2), 271-290.

Hariyani, Iswi; D. P., Serfiyanto; Serfiyani, C. Y. 2011. Merger, Konsolidasi, Akuisisi, \& Pemisahan Perusahaan: Cara Cerdas Mengembangkan \& Memajukan Perusahaan. Visimedia.

Hery. 2016. Analisis Laporan Keuangan. Grasindo.

Kasmir. 2018. Analisis Laporan Keuangan (I). PT. Raja Grafindo Persada.

Mishra, P. 2019. How have Mergers and Acquisitions Affected Financial Performance of Firms in Indian Manufacturing Sector? Eurasian Journal of Business and Economics, 12(23), 79-96. https:// doi.org/10.17015/ejbe.2019.023.05

Munawir, S. 2010. Aanlisis Laporan Keuangan (14th ed). Liberty.

Prasad, V. 2019. Impact of capital structure on financial performance of Small Finance Banks. International Journal of Research in Business Studies and Management, 6(4), 29-35.

Prasetyo, B. 2008. Analisis Kinerja Keuangan Pada Perusahaan Manufaktus Sebelum dan Sesudah Melakukan Merger dan Akuisisi di Bursa Efek INdonesia. Univesitas Muhammadiyah Surakarta.

Sharma, S. 2016. Measuring Post Merger Performance - A Study of Metal Industry. International Journal of Applied Research and Studies, 2(8). https://doi. org/10.20908/ijars.v2i8.9463

Sudana, I. M. 2011. Manajemen Keuangan Perusahaan. Teori dan Praktik. Erlangga.

Tang, A. C. 2015. Mergers and Acquisitions and its Effects on Firm Performance: A New Look. Proceedings of the DLSU Research Congress, 3(2004), 1-7.

Van Horne, James C; Wachowicz, John M., J. alih bahasa Q. M. 2012. Prinsip-prinsip Manajemen Keuangan (13. Buku I). Salemba Empat.

Zen, N., Achsani, N. A., \& Andati, T. 2016. The Impact of Acquisition on Financial Performance of Pt. Abc. Indonesian Journal of Business and Entrepreneurship, 2(3), 177-186. https://doi. org/10.17358/ijbe.2.3.177 


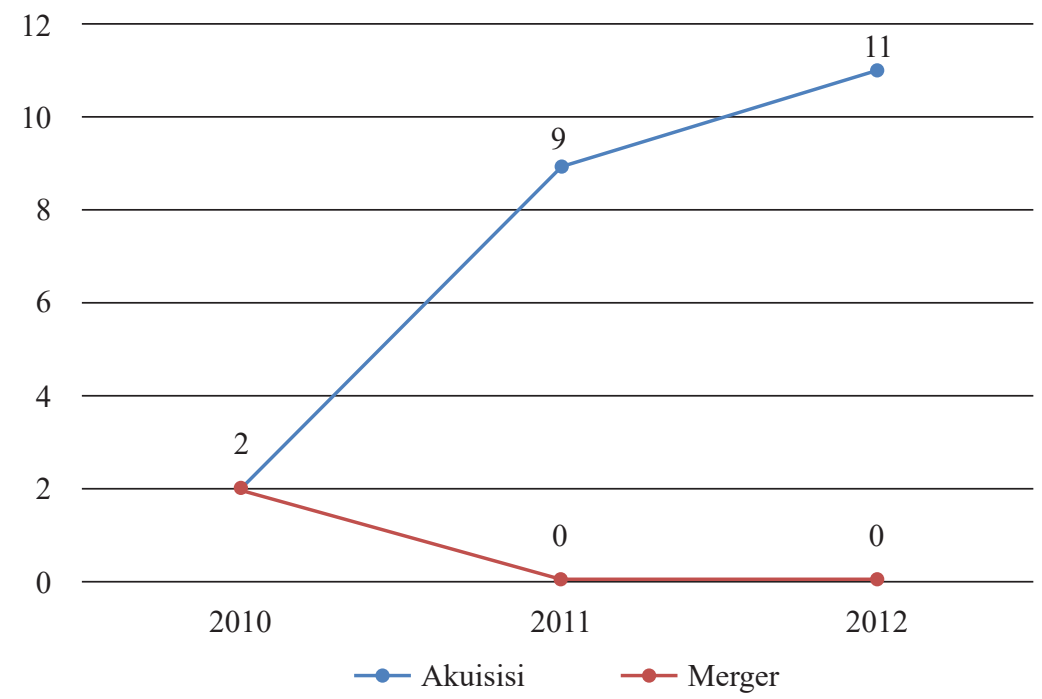

Gambar 1. Jumlah Akuisisi dan Merger Pada Perusahaan yang Terdaftar di BEI tahun 2011 - 2012

Tabel 1. Hasil Analisis Deskriptif

\begin{tabular}{lccccc}
\hline & $N$ & Minimum & Maximum & Mean & Std. Deviation \\
\hline Current ratio & 40 & .324 & 90.075 & 4.08718 & 14.061486 \\
Total asset turnover & 40 & .0021 & 3.2600 & .744244 & .9926211 \\
Debt to equity ratio & 40 & .03 & 4.40 & .9933 & .84006 \\
Return on asset & 40 & -3.09 & 18.85 & 7.7300 & 5.29006 \\
Valid N (listwise) & 40 & & & & \\
\hline
\end{tabular}

Tabel 2. Kinerja Keuangan

\begin{tabular}{lccccc}
\hline Kinerja & 2010 & 2011 & 2012 & 2013 & 2014 \\
\hline Likuiditas (CR) & 12.83983 & 2.972704 & 1.576608 & 1.554802 & 1.491939 \\
Aktivitas (TATO) & 0.757356 & 0.867028 & 0.716116 & 0.724465 & 0.656254 \\
Leverage (DER) & 0.94625 & 0.94 & 0.84 & 1.02375 & 1.216472 \\
Profitabilitas (ROA) & 9.02 & 9.38 & 8.49 & 7.02 & 4.74 \\
\hline
\end{tabular}

Tabel 3. Hasil Uji t-test Sample Related

\begin{tabular}{|c|c|c|c|c|c|c|c|c|}
\hline & \multicolumn{5}{|c|}{ Paired Differences } & \multirow[t]{3}{*}{$t$} & \multirow[t]{3}{*}{$d f$} & \multirow{3}{*}{$\begin{array}{c}\text { Sig. } \\
\text { (2-tailed) }\end{array}$} \\
\hline & \multirow[t]{2}{*}{ Mean } & \multirow[t]{2}{*}{$\begin{array}{c}\text { Std. } \\
\text { Deviation }\end{array}$} & \multirow[t]{2}{*}{$\begin{array}{l}\text { Std. Error } \\
\quad \text { Mean }\end{array}$} & \multicolumn{2}{|c|}{$\begin{array}{c}\text { 95\% Confidence Interval } \\
\text { of the Difference }\end{array}$} & & & \\
\hline & & & & Lower & Upper & & & \\
\hline CR sebelum - setelah akuisisi & 6.38438 & 22.40186 & 5.60047 & -5.55273 & 18.32148 & 1.140 & 15 & .272 \\
\hline TATO sebelum - setelah akuisisi & .12188 & .23230 & .05807 & -.00191 & .24566 & 2.099 & 15 & .053 \\
\hline DER sebelum - setelah akuisisi & -.17700 & .73666 & .18416 & -.56954 & .21554 & -.961 & 15 & .352 \\
\hline ROA sebelum - setelah akuisisi & 3.31905 & 3.03412 & .75853 & 1.70228 & 4.93582 & 4.376 & 15 & .001 \\
\hline
\end{tabular}

